\title{
Cross-sectional field trial to assess the efficacy of restricted application of deltamethrin $1 \%$ ready to use formulation: To adapt and develop cost-effective tsetse control strategy to be applied in Ethiopia
}

\section{Dereje Alemu Bekele ( $\nabla$ dalemu73@yahoo.com )}

Bedele Tsetse and Trypanosomosis Investigation and Control Center https://orcid.org/0000-0003-1208-9930

AhImedin Beshir Aliyu

Bedele Tsetse and Trypanosomosis Investigation and Control Center

Behablom Meharenet Gebregiyorgis

Kality Tsetse FlyMass Rearing and Irradication Center

\section{Tegegn Adugna Beyene}

Bedele Tsetse and Trypanosomosis Investigation and Control Center

\section{Research article}

Keywords: tsetse, trypanosomosis, bait technology, deltamethrin 1\%, insecticide-treated cattle, RAIC technique, costeffectiveness

Posted Date: June 30th, 2020

DOI: https://doi.org/10.21203/rs.3.rs-36173/v1

License: (c) (i) This work is licensed under a Creative Commons Attribution 4.0 International License. Read Full License 


\section{Abstract}

\section{Background}

Probability-based observational study design was used to collect the baseline data, data to isolate changes occurring overtime and data on last monitoring in which sampling involved stratified random selection of sampling units, since the surveying area is heterogeneous, at the outset, the area was isolated into subareas (strata) based on vegetation, climate, altitude, land use, distribution of human habitation, etc. into more or less homogeneous. Different trap traps design baited with odor attractants were deployed in a georeferenced locaitons. Then, animals were treated with deltamethrin $1 \%$, using hypodermic syringe, at belly and legs body parts, as $0.06 \mathrm{ml}$ of formulation per $1 \mathrm{~kg}$ of body weight which is less by $40 \%$ that needed for a whole body treatment regime The data processing was carried out based on quantitative data analyzing methods.

\section{Results}

The result of subsequent monitoring surveys depicted that the overall tsetse mean catch reduced by $78.6 \%$ from a mean catch of $17.3 \pm 8.6$ flies per trap per day of pre-control to $3.7 \pm 2.6$ flies per trap per day at last monitoring. And the reduction was found statistically significant; $p=0.000$. Consequentially, the overall mean trypanosome prevalence was dropped from a peak of 63 cases $(11.6 \% \pm 3.2)$ in November 2017 to the current level of 17 cases $(3.9 \% \pm 2.3)$ in June 2019 . This resulted in a $66.4 \%$ reduction in which the difference was found statistically significant; $p=0.000$. The overall mean PCV value has also improved by $1.5 \%$ from $24.9 \% \pm 3.2$ of the reference data to $26.4 \% \pm 3.4$ at last monitoring and the difference was found statistically significant; $p=0.002$.

\section{Conclusion}

As the findings of this field trial have proved, generally, insecticide-based control technique is one of the most reliable simplest techniques to rapidly suppress tsetse flies. Its cost effectiveness greatly enhances when it is applied in restricted application scenario. The technique has got a potential not only to reduce the amount of insecticide needed for the whole body application regimen by $40 \%$, but also a potential to adequately suppress tsetse flies consequentially, trypanosomosis.

\section{Background}

\section{An overview to the problem}

Tsetse fly species that are of major economic importance in Ethiopia are confined to semi-arid, sub-humid and humid lowlands of the southern and western regions between longitude $33^{\circ}$ and $38^{\circ} \mathrm{E}$ and latitude $5^{\circ}$ and $12^{\circ} \mathrm{N}$ which amounts to about 200,000 square kilometers. Across all tsetse infested areas of the country more than 14.8 million cattle are under direct exposure to the disease, though, at different degree of risks [1].

African animal trypanosomosis (AAT) is one of the major constraints to arable agriculture and livestock production and productivity in Ethiopia. Tsetse-transmitted animal trypanosomosis is a complex disease that directly and indirectly impacts the livestock and crop agriculture, respectively. As a result of direct consequence of the tsetse transmitted trypanosomosis people are continually evicted. The direct impacts are mortality and morbidity, milk yields are low and carcass is poor, calving survival rate reduced, disruption of oestrus cycle and reduction of conception rate, reduction in libido, affected animals lack stamina and strength; even more significant may be the 
indirect impact on crop production, land use, ecosystem structure and function, and human welfare. As a conesequence of trypanosomosis, the potential development of livestock and crop production is seriously constrained. $[2,3]$. A significant effect of the disease is that it prevents the use of animal traction. Consequentially, farmers have to rely on manual tillage of the land which is associated with much lower crop yield. The absence of draft animals due to trypanosomosis leads to delayed planting, lower crop yields and higher production costs; above and all, it deters resettlement patterns. The lack of oxen, in turn, compelled many farmers to abandon their farm land as a result of the widely distributed flies. This may have implications on the agro-ecosystems by reducing the amount of cultivated land, manure availability and the quality of land preparation. Generally, the socioeconomic and nutritional status of people in these tsetse infested areas, draft power facility and direct benefits of animals are also seriously inhibited.

Currently, the most widely used method to contain trypanosomosis is through the distribution of imported trypanocidal drugs. This costly therapy is essentially a palliative and not a long-term solution to the trypanosomosis problem. Therefore, the heavy reliance of livestock owners on trypanocides, the alarming emergence of resistance together with the low adoption of other alternatives have been increasingly recognized as a major constraint to livestock production in the area. Previous studies conducted in the Ghbe valley, [4] proved that the three trypanocides (Isomethamedium chloride, Diminazine aceturate and Homidium) used to control tsetsetransmitted trypanosomosis in domestic animals have been in use for over six decades; hence, resistance of trypanosomes has emerged to these currently available trypanocidal drugs. As a result, the livelihood of millions of resource poor livestock owners is crippled where by causing ill health and death to their animals. Generally, shortage of drugs, high treatment cost and development of drug resistance by the parasite in one hand and reduced crop production due to the negative effect of the disease on draft animals on the other, have necessitated a costly vector control programme.

Application of pour-on insecticide to livestock is an important means of controlling tsetse. The use of insecticides is the major method currently employed for tsetse control in Ethiopia. There has been significant success where insecticide control measures are properly implemented. However, for resource poor livestock keepers, use of this method is constrained by the consistently increasing high cost of imported insecticides. Therefore, one major problem here is how to maintain community interest if the cost of insecticide constantly increases? The reliable solution to minimize this problem is treating cattle in more cost-effective and technically feasible manner; on only those regions of the animals' body where most tsetse feed, the legs and belly parts.

As previous studies on direct observation of the vectors proved, (Glossina morsitans morsitans, G. pallidipes, G. brevipalpis, G. austeni, G. tachinoides and G. palpalis palpalis) tsetse consistently land and feed on the legs of cattle, $[5,6,7]$. Following these results, the restricted application control technique was assessed at the field to select and adapt, in Ethiopia situation, effective and cheaper (lesser by $40 \%$ amount of insecticide per individual animal) application method, [8]. This adaptable and problem oriented field trial on deltamethrin $1 \%$ ready to use formulation, aimed at evaluating the technique efficacy and cost-effectiveness was carried out where three tsetse fly species are found: namely Glossina morsitans submorsitans, G.pallidipes and G. fuscipes fuscipes surving as cyclical transimiters of Trypanosoma congolense, T. vivax and T. brucei, [9],causing significant depletions on agricultural production and socio-economic development at large.

\section{Results}

Loading [MathJax]/jax/output/CommonHTML/jax.js logical data

Page 3/19 
The base line entomological survey was carried out in different ecological situations, varying from densely infested woodland and gallery forests on the valley floor and it's escarpment from the acacia woodland into open savannah grassland nearly $12 \mathrm{kms}$ of the Ghibe valley to areas where flies could hardly be detected. Accordingly, a total of 75 biconical, monoconical and pyramidal trap designs baited with odor attractants, placed in three different dispensers, were erected. Consequently, of total traps deployed, 1298 three species of tsetse flies namely G.pallidipes, G. $m$ submorsitans and G. f. fuscipes were caught that accounted for an overall mean catch of 17.3 \pm 8.6 flies per trap per day and attributed to an overall apparent density of 8.7 flies per trap per day. Regarding their relative density, the most Glossina species caught was G. f. fuscipes with a mean catch of 10.7 \pm 6.3 (9.3-12.2) flies per trap per day followed by G. m. submorsitans with a mean catch of $4.9 \pm 2.9$ (4.3-5.6) flies per trap per day and G.pallidipes 1.6 \pm 1.3 (1.3-1.9), (Table 1). The one factor-ANOVA statistical test method depicted that the difference in mean catch, among the species, was found statistically significant; $F_{0.05}=95.4 ; p=0.000$. Within each group of flay, more female flies were captured and the difference in sex proportion of the species was found statistically significant; $F_{0.05}=100.7 ; p=0.000$.

On the other hand, to determine trypanosomes infection rate in tsetse, dissection on proboscis, salivary glands and mid-gut of the flies was done on a total of 239 flies of the aforementioned species. Of total dissected flies six were found infected with T.congolense and T.vivax that accounted for an overall fly infection rate of $2.51 \%$. Regarding their proportion, of total dissected flies, 174 (72.8\%) were G. f. fuscipes while $19.7 \%, \mathrm{n}=47$ and $7.5 \%$, $\mathrm{n}=18$ were G.m.submorsitans and G.pallidipes, respectively. An infection rate of T.congolense type, $n=4,66.7 \%$, was prevalent in all species; in which the highest prevalence was observed in G.m.submorsitans while in the remaining two species were equally prevalent.On the other hand, $n=2,33.3 \%$ of the infection was arouse due to T.vivax and both were detected in G. f. fuscipes but none of the flies were found infected with T.brucei type alone and mixed infection in any combination.

Side by side to entomological survey, a total of 542 randomly selected animals were examined. Of these 63 were found infected with T.congolense, T.vivax, and mixed infection T.congolense occurring together with T.vivax/T.brucei. The overall trypanosome prevalence was as high as $11.62 \% \pm 3.2$ having an overall mean PCV value of $24.9 \% \pm 3.2$. The mean PCV-value recorded for aparasitaemic animals, $25.4 \% \pm 2.9$, exceeded that of parasitaemics, $21.6 \% \pm 3.0$, on average by $3.8 \%(3.0,4.6)$, while $39.1 \%(n=212)$ of examined animals recorded a mean PCV value below the threshold (25\%). Regarding their relative proportion, $(n=42,66.7 \%)$ of the infection with a mean PCV-value of $21.2 \pm 2.9$ was arouse due to T.congolense followed by T.vivax $(n=17,26.9 \%)$ with a mean PCV-value of 22.6 \pm 3.4 and mixed infection, $(n=4,6.3 \%)$ had mean PCV-value record of $21.5 \pm 2.9$ while $(n=479$, $88.4 \%$ ) of the animals with a mean PCV-value of $25.4 \pm 3.0$ were found negative with BCT technique. The post hoc test which suggests where the difference lie, depicted that only the mean PCV-value of non-infected animals statistically differed from each group of trypanosome infected animals (Table 1).

Table 1. Pre control multiple comparison (post hoc test) of PCV value 


\begin{tabular}{|lllll|}
\hline Parasite species & Parasite species & Mean PCV difference & Std. Error & Sig. \\
& & & & p-value \\
\hline \multirow{2}{*}{ T.congolense } & T.vivax & -1.5 & 0.9 & 0.538 \\
\cline { 2 - 5 } & Mixed & -0.3 & 1.6 & 1.000 \\
\cline { 2 - 5 } & Negative & -4.2 & 0.5 & 0.000 \\
\hline \multirow{2}{*}{ T.vivax } & Mixed & 1.1 & 1.7 & 1.000 \\
\cline { 2 - 5 } & Negative & -2.7 & 0.7 & 0.001 \\
\hline
\end{tabular}

Post-intervention entomological and parasitological data

Twenty months after the onset of the study to monitor the progress of the intervention against tsetse fly apparent density, 56 different trap designs baited with odor attractants were set up. Of these set up traps a total of 218 aforementioned fly species were caught that accounted for an overall apparent density of 1.8 flies per trap per day with mean catch of $3.7 \pm 2.6$ flies per trap per day. Regarding their relative abundance, more G.m.submorsitans flies were caught with a mean catch of $1.7 \pm 1.4 ;(1.3,2.0)$ followed by $G$. f. fuscipes $1.5 \pm 1.7 ;(1.1,2.0)$ and G.pallidipes $0.7 \pm 0.9 ;(0.4,0.9)$. The difference in relative mean catch of flies was found statistically significant, $F=8.3 ; P=0.000$. Alongside to the entomological survey, a total of 124 the aforementioned fly species were dissected, of which four (3.2\%) were found positive. In order of their size, the highest number, $58(46.8 \%)$, of dissected flies were G.m.submorsitans, followed by G.pallidipes 34 (27.4\%) and G.f.fuscipes 32 (25.8\%). Accordingly, none of G.m.submorsitans flies was found positive while three of $G$. $f$. fuscipes flies $(9.3 \%)$ were found positive for only T.vivax and one (2.9\%) of G.pallidipes was found infected with T.congolense.T.vivax type infection accounted for a proportion of $75 \%$ followed by T.congolense, $25 \%$.

On the other hand, to determine the progress of the parasite control a total of 432 animals were examined. Of these, 17 were found infected with T.congolense, T.vivax, and mixed infection T.brucei occurring together with T.congolense. The overall trypanosome prevalence was as high as $3.9 \% \pm 4.9$ having an overall mean PCV value of $26.4 \% \pm 3.3$. However, $(n=30,9.7 \%)$ of the non-infected animals and $n=16,94.1 \%$ of infected animals recorded a mean PCV-value below the threshold. The mean PCV-value recorded for aparasitaemics, $26.4 \% \pm 3.3$ was higher from parasitaemics, $22.6 \% \pm 3.1$, on average by $3.8 \% \pm 0.8 \mathrm{SE}(2.2,5.3)$ and the difference was found statistically significant; $t_{0.05}=3.5 ; p=0.000$. Regarding their relative prevalence, $(n=12,70.6 \%)$ of the infection was arouse due to T.vivax, having mean PCV-value of $22.3 \% \pm 2.3$ followed by T.congolense type infection $(n=4,23.5 \%)$ with mean PCV-value of $20.8 \% \pm 1.3$ and mixed infection, $(n=1,5.9 \%$ ), with relative mean PCV-value of $25 \%$ but no T.brucei type infection alone was observed

\section{Discussion}

The tsetse fly survey well corresponds to the general classification of tsetse flies in terms of their habitat and requirements, particularly to the ecology of tsetse species found in the Ghibe valley, southwest of Ethiopia, [9]. The results obtained from this trial show that, tsetse overall apparent density significantly reduced from a mean catch of $17.3 \pm 8.6$ flies per trap per day of pre-control to $3.7 \pm 2.6$ flies per trap per day at last monitoring. This resulted in 
a 78.6\% overall mean catch reduction. According to t-test statistics for equality of overall mean catch of flies preand post-intervention, the mean catch difference, $13.6 \% \pm 1.2 \mathrm{SE}$, was found statistically significant; $p=0.000$.

The quantitative and qualitative variation in tsetse population, population dynamics, depend directly on biotic and abiotic factors in the environment, seasonal variation in the population size or more precisely in the apparent density is linked essentially to the life span of the imagos, on one hand, and the pupal mortality on the other, [10]. Having in mind the environmental factors contribution on tsetse density, the observed reduction in tsetse density was mainly associated with the pronounced effect of the insecticide based intervention in which it attributed on the adult tsetse shortened life span. This is because, the last monitoring survey was carried out after the short rainy season (April-May) in June 2019 when biotic and abiotic factors in the environment favored tsetse reproduction; during when the life span of the adults increases and the duration of the development of the pupa reaches its optimum, however, the presence of suitable habitat alone is not always in favor of the flies' reproduction. In this regard, Hargrove, J. W. (2000), [11], stated that as vegetation is vital for providing shade and maintains a suitable microclimate for tsetse as well as habitat for their hosts, and provides flies enough moisture, replenishment of tsetse density rapidly gets better as soon as the first rains have reduced the ambient and soil temperature. Thus, the rapid decline in tsetse density was caused by the pour-on based intervention. This can be evidenced by the drastic decline of tsetse (by $76.7 \%$ ) realized three months after nearly 18,311 animals were treated at first time, in November 2017, (Graph 1). Incidentally, with this amount of insecticide used, only 13,104 animals could have been treated if the standard treatment regime was followed, and this signifies a $40 \%$ reduction in the amount of insecticide used. The Pearson Chi-Square test statistics too evidenced the presence of strong association between the intervention and tsetse density reduction; $X^{2}{ }_{0.05}=73.5 ; p=0.000$.

Graph 1. Impact of RAIC technique on tsetse density and its future linear trend to suppress tsetse

Following the restricted application of insecticide at a density of 15 animals per $\mathrm{km}^{2}$ area with nearly three months base, at last monitoring, the relative abundance of G.f.fuscipes was significantly declined from a pre-intervention mean catch by $91.3 \%$ followed by G.pallidipes, (76.1\%) and G.m.submorsitans, (55.1\%), (Table 2), and the relative reduction within the groups pre- and post-intervention was found statistically significant; $p=0.000$. In this context, two aspects are important for the largest reduction observed in G.f.fuscipes: firstly, this species largely have a preference for feeding on bovid bloodmeal as a result fly-cattle contact was high; secondly, cattle in the present study area graze deep into the valley floor where there is suitable habitat for the specified species in which the flycattle contact, once more was very high; thus, these facts permits us to conclude that G.f.fuscipes species in the present area, are the main vectors of trypanosomes; however, a blood meal analysis was not done. Similar conclusion can also be made regarding with G. pallidipes; since it was the second most reduced species. This conclusion is in consistence with the previous studies conducted by [12] who stated that G. pallidipes and G. f. fuscipes feed mainly on livestock and G. pallidipes is the main vector of animal trypanosomosis.

Table2.Relative FTD of tsetse flies pre- and post-intervention time and their relative reduction 


\begin{tabular}{|c|c|c|c|c|c|c|c|c|c|c|}
\hline $\begin{array}{l}\text { Study } \\
\text { Area }\end{array}$ & Fly Species & $\begin{array}{l}\text { Survey } \\
\text { Time }\end{array}$ & $\begin{array}{l}\text { No. } \\
\text { of } \\
\text { Set } \\
\text { up } \\
\text { Traps }\end{array}$ & $\begin{array}{l}\text { M. } \\
\text { Catch/ } \\
\text { Trap }\end{array}$ & SD & $\begin{array}{l}\text { MCD } \\
(95 \% \\
\mathrm{Cl})\end{array}$ & $\begin{array}{l}\text { SE } \\
\text { Mean }\end{array}$ & R.FTD & $\begin{array}{l}\mathrm{RR} \\
(\%)\end{array}$ & $\begin{array}{l}\text { Sig. } \\
(P- \\
\text { value }) \\
\\
\text { at } \\
0.05 \\
\text { level }\end{array}$ \\
\hline \multirow[t]{6}{*}{$\begin{array}{l}\text { Botor } \\
\text { Tolay }\end{array}$} & \multirow[t]{4}{*}{$\begin{array}{l}\text { G.m.sm } \\
\text { G.pallidipes }\end{array}$} & \multirow{2}{*}{$\begin{array}{l}\text { Pre- } \\
\text { Intervention } \\
\text { Post - } \\
\text { Intervention }\end{array}$} & 75 & 4.9 & 3.9 & $\begin{array}{l}3.3 \\
(2.5 \\
4.1)\end{array}$ & 0.4 & 2.5 & 68.0 & 0.000 \\
\hline & & & 56 & 1.6 & 1.3 & & & 0.8 & & \\
\hline & & \multirow{2}{*}{$\begin{array}{l}\text { Pre- } \\
\text { Intervention } \\
\text { Post- } \\
\text { Intervention }\end{array}$} & 75 & 1.6 & 1.3 & $\begin{array}{l}1.0 \\
(0.6 \\
1.4)\end{array}$ & 0.2 & 0.8 & 62.5 & 0.000 \\
\hline & & & 56 & 0.6 & 0.9 & & & 0.3 & & \\
\hline & \multirow[t]{2}{*}{ G. $f . f$} & $\begin{array}{l}\text { Pre- } \\
\text { Intervention }\end{array}$ & 75 & 10.7 & 6.3 & \multirow{2}{*}{$\begin{array}{l}9.3 \\
(7.6 \\
11.0)\end{array}$} & \multirow[t]{2}{*}{0.9} & \multirow[t]{2}{*}{5.3} & \multirow[t]{2}{*}{86.9} & \multirow[t]{2}{*}{0.000} \\
\hline & & $\begin{array}{l}\text { Post - } \\
\text { Intervention }\end{array}$ & 56 & 1.4 & 1.7 & & & & & \\
\hline
\end{tabular}

i.e. $M$. Catch/Trap=Mean Catch per Trap; $S D=S t a n d a r d ~ D e v i a t i o n ; M C D=$ Mean Catch Difference; $S E$ Mean= Standard Error Mean; R.FTD= Relative Fly per Trap per Day; RR=Relative Reduction

Despite a high prevalence of multiple-drug resistant trypanosomes widespread in the target area, the overall mean trypanosome prevalence among the herds dropped from 11.6\% \pm 3.2 in November 2017 to the current level of $3.9 \%$ \pm 2.3 . This resulted in an overall of reduction by $66.4 \%$ in which the reduction was found statistically significant; $\mathrm{p}=0.000$. Unlike to pre-intervention period, the dominance of $T$.congolense being a major cause of infection (63.5\%) was reverted, at last monitoring by T.vivax type which accounted for $70.6 \%$ of the overall prevalence while the former accounted for a proportion of $23.5 \%$. Significantly higher proportion of infection due to T. congolense, during pre-intervention period, signified cyclical transmission domination than mechanical. The widespread occurrence of T.vivax type infection at last monitoring, on the other, has got its own advantage for the improved general health levels and productivity of livestock, as it is considered being less virulent for cattle than $T$. congolense, which appears to cause more sever effect than T.vivax, which could be manifested by the mean PCVvalue. Additionally, the possible situations of the influence of trypanocidal drugs on trypanosome infection type never be neglected, [14]. They referred as the higher in T.congolense infection rate in tsetse-infested area could be resulted due to ineffective drug treatments against it to the same degree as T.vivax. This is in compliance with the present area pre-intervention time, where the curative and prophylactic capacities of the three trypanocides have been impaired as a result of widespread occurrence of drug resistance by the parasites. Nonetheless, the presence of high proportion of $T$. congolense infection is mainly associated with its number of antigenic variability.

Above all, the rare detection of $T$. brucei infection in sampled animals and its absence in dissected tsetse, may be attributed to the longer development cycle and complex pathway that it takes in the fly which hinder its survival and maturation especially when the life span of the fly is shorten,. Besides, in contrast to T.congolense and T.vivax, infection with trypanzoon species is characterized by generally low parasitaemia and a marked invasion of tissue, the parasite has got a lesser probability to be picked up by the fly while ingesting the blood meal, consequentially, 
The epidemiology of African animal trypanosomosis (AAT) is almost entirely dependent on tsetse flies. As a result, the trypanosomal infection type in tsetse is of prime importance in determining the type of infection the animals to be contracted with. Fly species differ in their capacity to transmit trypanosomes. Morsitans group flies, except for G.austeni, are good vectors of all trypanosome species. To the contrary, Palpalis group species appear to be poor vectors of most trypanosome species except certain stocks of West African T.vivax, although G.f.fuscipes can be important vector of human infective trypanosomes, [15]. This vectoral capacity difference is associated mainly with the type of lectins found in the gut of different species of flies. It has been established that lectin plays a role in determining refractoriness to infection by killing procyclic trypanosomes, whilst symbiotic bacteria are involved in determining susceptibility to infection by a process that results in inhibition of these midgut lectins and thus reduces their killing effect (blocks the lectin-mediated trypanocidal activity), [16]. Glucosil lectin is found in morsitans and fusca groups whose action can be inhibited by D-(+) glucosamin which is secreted by maternally inherited Rickettsia-like organisms (RLO) while palpalis group species possess the galactosil lectin whose action is not inhibited by D-(+) glucosamin. That's why, palpalis group tsetse species are less refractory to trypanosomes infection as a result of the effect of the non-cellular factor, galactosyl lectin. It acts as agglutinin, which interferes on trypanosome survival and maturation. Based on these general influences on Glossina infection rates, neither all species nor all individuals within a species are equally efficient, [17].

Provided that G.f.fuscipes outnumbered the sum density of G.m. submorsitans and G.pallidipes before the onset of the intervention, and the former is considered good vectors of T.vivax, the vivax type infection proportion in cattle was lower than congolense type. As shown in the present study, however, both groups of tsetse (riverine and savannah) harbored T.congolense, the highest, (75\%), infection rate of T.congolense in the flies was observed in G.pallidipes and G.m.submorsitans which indicates the important role of these species, playing significant role in transmitting T.congolense while they were prevalent with relatively lower number; this is in agreement with many studies which has shown that palpalis group flies are poor vectors of trypanosomes especially, T.congolense. Additionally, the possible situations of the influence of trypanocidal drugs on trypanosome infection type never be neglected, [14]. They referred as the higher in T.congolense infection rate in tsetse-infested area could be resulted due to ineffective drug treatments against it to the same degree as T.vivax. This is in compliance with the present area pre-intervention time, where the curative and prophylactic capacities of the three trypanocides have been impaired as a result of widespread occurrence of drug resistance by the parasites. Nonetheless, the presence of high proportion of T. congolense infection is mainly associated with its number of antigenic variability.

Nonetheless, post intervention period even if these savannah species were more abundant than G.f.fuscipes, congolense type infection in cattle, by far lessen from vivax type. In this context, some possible explanations can be given based on the epidemiology of trypanosomosis: firstly, higher proportions of infection were transmitted mechanically as compared to cyclical transmission, which in turn signifies the importance of nuisance flies in the area, [18]; this is because T.vivax is the species most likely to be transmitted mechanically, other species of trypanosomes pathogenic to cattle can also be transmitted and Glossina spp. may also act as mechanical as well as cyclical vectors [19]; secondly, the proportion of T.vivax infections in tsetse increases under adverse environmental conditions (in our case the progressed tsetse control) when the flees' shortened life span prevented the completion of cyclical development of the Nannomonas (T.congolense) and Trypanzoon (T.brucei) trypanosome species [20]; consequentially, transmission of these parasites were hindered; thirdly, high T.vivax infection rates in flies arouse for the fact that T.vivax develops in the proboscis, it is far from the action of antitrypanosomal factor of the flies' gut, in which beside to shorter development cycle it follows, absence of this trvaanosomal action on T.vivax enabled it to be found in higher proportion in tsetse consequentially, in naturally Loading [MathJax]/jax/output/CommonHTML/jax.js 
infected cattle. Finally, higher T.vivax type infection in cattle usually encounters when the overall prevalence of trypanosomosis in cattle is low. Off course, the species of animal on which tsetse fed, exerts the greatest influence on the infection rate in flies. Whiteside, E.F (1958), [21] and Jordan, A. M. (1986), [22] identified at least 18 major variables influencing the potential of trypanosomes to develop in tsetse flies (the epidemiology of African animal trypanosomosis), which relate to interactions of tsetse (as endogenous factors associated with tsetse), ecological factors and parasite and host factors, .

One of the major effects of infection with pathogenic trypanosomes is anemia. Measurement of anemia gives a reliable indication of disease status and is correlated with parasitaemia-the higher the parasitaemia, the lower the PCVs. As a result of decline of trypanosome prevalence in the herds, the overall mean PCV-value of animals improved on average by $2.0 \%$. Thus, PCV is a good indicator of the health status of the herd in an endemic area, which negatively correlates to disease incidence. Nonetheless, $44.3 \%$ of the animals' mean PCV values during preintervention period and $28.9 \%$ of the animals during last monitoring were below the threshold of $25 \%$ normal PCVvalue.

In this regard, partially or semi-trypanotolerant cattle living in and in close proximity to the target areas were observed. Some animals achieved better control of parasitaemia while they were infected by maintaining PCV in its normal range and this could be an indicative that deferent serodemes of trypanosomes are circulating in the area, against to which individual animals developed resistance, [23]. On the other hand, some animals PCV-value was lower than the threshold level, while they were not infected with trypanosomes, which suggests that anemia is a multi-factorial problem in the area in which management, exercise and heat stress could be attributable [24].However, management factors share the major contributions to anemia, contribution of concurrent infections such as internal, external parasites and other heamoparasites is not negligible. The degree of anemia is directly correlated with the loss of productivity performance and could be a major contributor to death of trypanosomeinfected cattle.

Therefore, in areas where multiple drag resistance is widespread, the use of 'pour-on' insecticides, may help as a more sustainable method of tsetse control, consequentially, trypanosomosis, even without integrating the technique with other tsetse control methods. Nonetheless, the effectiveness of this technique works best where livestock are the main host of tsetse. The results of this field trial are in consistent with the findings of Leak, S.J.A., 1995 , in which

Table 3. Summary statistics for pre- \& post-intervention relative trypanosome prevalence and mean PCV value 


\begin{tabular}{|c|c|c|c|c|c|c|c|c|}
\hline $\begin{array}{l}\text { Intervention } \\
\text { time }\end{array}$ & $\begin{array}{l}\text { Infection } \\
\text { type }\end{array}$ & $\begin{array}{l}\text { No of } \\
\text { animals } \\
\text { infected }\end{array}$ & $\begin{array}{l}\text { Mean } \\
\text { PCV } \\
(95 \% \\
\text { Cl) }\end{array}$ & $\begin{array}{l}\text { Std. } \\
\text { Dev. }\end{array}$ & $\begin{array}{l}\text { Relative } \\
\text { prevalence } \\
(\%)\end{array}$ & $\begin{array}{l}\text { Disease } \\
\text { proportion } \\
(\%)\end{array}$ & $\begin{array}{l}\text { Relative } \\
\text { reduction } \\
(\%)\end{array}$ & $\begin{array}{l}\text { Sig. at } \\
0.05 \\
\text { level }\end{array}$ \\
\hline $\begin{array}{l}\text { Pre- } \\
\text { intervention }\end{array}$ & $\begin{array}{l}T . \\
\text { congolense }\end{array}$ & 40 & $\begin{array}{l}19.4 \\
(17.6 \\
20.5)\end{array}$ & 4.3 & 7.4 & 65.6 & 90 & $P=0.000$ \\
\hline $\begin{array}{l}\text { Post- } \\
\text { intervention }\end{array}$ & & 4 & $\begin{array}{l}20.8 \\
(19,0 \\
22.0)\end{array}$ & 1.3 & 1.2 & 23.5 & & \\
\hline $\begin{array}{l}\text { Pre- } \\
\text { intervention }\end{array}$ & T.vivax & 17 & $\begin{array}{l}24.4 \\
(21.6 \\
27.0)\end{array}$ & 5.2 & 3.1 & 27.9 & 29.4 & $P=0.000$ \\
\hline $\begin{array}{l}\text { Post- } \\
\text { intervention }\end{array}$ & & 12 & $\begin{array}{l}22.3 \\
(19.0 \\
26,0)\end{array}$ & 2.3 & 3.6 & 70.6 & & \\
\hline $\begin{array}{l}\text { Pre- } \\
\text { intervention }\end{array}$ & Mixed & 4 & $\begin{array}{l}20.0 \\
(13.0 \\
26.9)\end{array}$ & 4.4 & 0.7 & 6.5 & 75 & $P=0.000$ \\
\hline $\begin{array}{l}\text { Post- } \\
\text { intervention }\end{array}$ & & 1 & 25.0 & & & 5.9 & & \\
\hline $\begin{array}{l}\text { Pre- } \\
\text { intervention }\end{array}$ & Negative & 479 & $\begin{array}{l}26.4 \\
(18.0 \\
37.0)\end{array}$ & 3.6 & & & & \\
\hline $\begin{array}{l}\text { Post- } \\
\text { intervention }\end{array}$ & & 415 & $\begin{array}{l}26.8 \\
(26.4 \\
17.1)\end{array}$ & 3.3 & & & & \\
\hline
\end{tabular}

$95 \% \mathrm{Cl}=$ Confidence interval; Std.. Dev $=$ Standard Deviation

ITC control technique used in the present area, with a standard scenario that aimed at reducing G.pallidipes and $G$. m. suhmorsitans populations at Tolley/Gullele using cypermethrin $2 \%$ 'pour-on' formulation [25].

The standard (application of insecticide on the back of cattle) tsetse control technique so far employed, has got a potential to reduce both tsetse population and the disease prevalence within a short time. However, treating cattle with insecticide is an increasingly important means of controlling tsetse flies as livestock keepers in particular and the national economy at

large, it has been hindered by high cost of the insecticide. Use of this control method with lesser amount in more cost-effective manner could be a reliable solution to the problem. In this regard, restricted application of insecticides to cattle has been recognized as a cheap, safe and environment friend farmer-based method to control tsetse and trypanosomosis, [26]. The present findings have assured that the restriction of pyrethroid application to only the belly and legs parts of the body by far reduces not only the amount of insecticide needed per application, according to the present trial by $40 \%$ that needed for whole body application. They have also proved its great potential to suppress tsetse population, consequentially, trypanosomosis incidence to prescribed low levels. The technique could be more useful in areas where the creation of fly-free zones is challenging and reinvasion pressure Loading [MathJax]/jax/output/CommonHTML/jax.js it, compared with targets as nuisance flies and ticks may also be 
controlled. Since the whole body treatment regime can contaminate the dung sufficiently to affect dung fauna, thereby threatening the important role that such fauna play in dung dispersal, and hence soil fertility and the productivity of pastures and crops [27]. The occurrence of trypanosomal infections in areas apparently free of tsetse promoted that infection can be maintained in nature by the mechanical transmission of trypanosomes by other heamatophagous flies $[28,29]$. As other study has shown, since other biting flies concentrate on the lower legs and belly [30] the technique is applicable even for biting flies (e.g. Stomoxys, Tabanus spp. etc.) especially during the late rainy season when these flies are more abundant. Besides, as is proved by [31], Anopheles arabiensis Patton (Diptera: Culicidae) is the most widespread vector of malaria in the Afrotropical Region. Because Anopheles arabiensis feeds readily on cattle as well as humans, the insecticide-treatment of cattle as employed to control tsetse (Diptera: Glossinidae) and ticks (Acari: Ixodidae) might simultaneously affect the malaria vectorial capacity of this mosquito.

Ultimately, application of insecticide in standard or restricted scenario does not have a significant difference in tsetse suppresion except the later system lessens the amount of insecticide used and the impact on non-target organisms. As is shown in the above graph, the technique linear trend to suppress the vector can lead to dramatic decline of tsetse populaiton to close to zero, if repeated treatement of animals is achieved. Tsetse control (eradication if possible) is the most reliable and effective alternative strategy available to date, towards adequately reducing and finally removing tsetse transmitted trypanosomosis risks and losses.

\section{Conclusions}

The result of this field trial demonstrated that RAIC control technique not only reduced the population size of tsetse flies but also the prevalence of Trypanosoma spp in cattle with a relatively cost-effective manner. First and foremost, the control of tsetse would enable the livestock economy to grow, thereby reducing mortality and improving the general health of animals. The present findings confirmed the cost-effectiveness of using ITC, especially when applied in restricted scenario, to control both tsetse flies and the attendant disease they transmit. To sum up, both direct and indirect benefits derived from the technique have large impacts on the overall balance between livestock and agricultural production and hence contribute to the goals of poverty reduction thereby enhancing incomes of the rural community. Since, the technique has not yet exhausted its potential to suppress tsetse with relatively lower amount, further study need to be carried out to maximize the economic benefit derived from it either alone or integrating it with other tsetse control techniques.

\section{Materials And Methods}

\section{Background to the study area}

This initial trial of RAIC in Ethiopia was conducted in area of $>850 \mathrm{~km}^{2}$ located along side of the Ghibe valley in Boter Tolay district located at grid references of $8^{\circ} 19^{\prime}$ to $8^{\circ} 45^{\prime} 35^{\prime \prime} \mathrm{N}$ latitude and $37^{\circ} 45^{\prime}$ to $38^{\circ} 71^{\prime} 42^{\prime \prime} \mathrm{E}$ longitude where a high drug-resistant trypanosomes are widespread. The Ghibe River is big perennial and is tributary of the Omo River which flows into south wards along the rift valley into Lake Turkana on the Ethiopian/Kenyan border. The area has got sub humid lowland climate that occurs between 500 at the valley floor and 1500 meters above sea level at its escarpment. The area receives reliable rainfall with an average of $900 \mathrm{~mm}$ precipitation per annum and the mean monthly maxi-mum temperature ranges from 29.8 to $44.0 \circ \mathrm{C}$ [32]. The main rainy season lasts from mid-June to late September and the shorter one from April to May. 
The predominant farming system of the area is characterized by mixed livestock and crop production, with livestock playing a vital role in agricultural activities, nutritional values and income generation. An East African Zebu type breed of cattle, which are also known as Abyssinian short-horned zebu, found in the study areas. This type of cattle breed is characterized by a pronounced susceptibility to trypanosomosis; as high prevalence rate, high drug resistance and high number of treatments [33]. Cattle, in the target area, are kept under traditional extensive husbandry system with communal herding, [34]. Along the Ghibe drainage lines and other its principal tributaries valley flanks, high gallery forests are found. The most common woody vegetation in the valley floors and their escarpments identified as Accacia abyssinica, Accacia seyal, Croton macrostachys and Combretum species. Wild animals that have been seen within the total area of the districts that serve as potential tsetse host include, roan antelope, warthog, bush pig, Colobus monkey, rabbit hyena, hippopotamus bush back, baboon (Personal communication with Regional Resource Bureau).

\section{Statistical test analyses}

To this end, data on individual animals parasitological and hematological and data on entomological surveys inserted into MS Excel Spread Sheet Program (Microsoft Corp.) to create database and transferred to SPSS version 26 software of the computer programme. The test statistics was used to test the null hypothesis $\left(\mathrm{H}_{0}\right)$ that stated as restricted application of deltamethrin $1 \%$ ready to use formulation would reduce tsetse apparent density, consequentially, trypanosome prevalence as equally as whole body treatment regime does.

\section{Parasitological survey}

\section{Sample size determination}

The prevalence assumption was made based on previous survey that had been carried out by NTTICC, 20\%, [35] Subsequently, to accurately estimate the mean number of cattle infected with trypanosomosis, the sample size determination was done based on the standard deviation of previous trypanosomosis prevalence, at $99 \%$ confidence level and 5\% acceptable error. Sample size was determined using formula of [36]. Accordingly, 429 animals were sufficient to estimate the prevalence, but 542 animals were sampled during a reference data collection and 432 animals at last monitoring. And this allowed us being confident that amongst the whole population there is $99 \%$ chance that the mean is within the acceptable error limit of $5 \%$.

The data processing was carried out based on quantitative data analyzing methods. The collected data were subjected to univariate one-way ANOVA (Analysis of Variance) to explore the relative proportion of tsetse species caught, the identified trypanosomes relative prevalence and their respective mean PCV-value. And to determine where the difference lays Bonferonni procedure was used. On the other hand, independent t-test, Matched pair ttest, Student t-test were used to analyze the difference in overall tsetse density and trypanosome prevalence preand post-control data, and Chi-square test statistics was employed whether the results obtained were arose due to the intervention or by chance for both entomological and parasitological data. Descriptive statistics, such as table, frequency distribution, means, percentiles, standard error, standard deviation and graphs were employed.

\section{Study design}

\section{Entomological}

Probability-based cross-sectional study design was used to collect the baseline data, data to isolate changes Loading [MathJax]/jax/output/CommonHTML/jax.js ing in which sampling involved stratified random selection of sampling 
units [37]. Regarding entomological surveys, since the surveying area is heterogeneous, in order to avoid the possible biasness while determining the apparent density of flies that could be arisen due to their seasonal changes in distribution, surveys were carried out by the method of stratified sampling that repeated for each surveying time after designing a sampling strategy. At the outset, the target area was isolated into subareas (strata) based on vegetation, climate, altitude, land use, distribution of human habitation, etc. into more or less homogeneous [38]. Having done this, biconical, monoconical and pyramidal trap designs baited with odor attractants such as octenol (1-oct-3-nel), acetone $\left(\mathrm{C}_{8} \mathrm{H}_{16} \mathrm{O}\right)$; and 3 weeks old treated cattle urine, [39], placed in three different bait dispensers, were deployed along transects from the acacia woodland into open savannah grassland nearly $12 \mathrm{kms}$ of the Ghibe valley and its escarpment in both the late rainy and the dry seasons at the same trapping sites. Traps were positioned for two consecutive days with mean interval between traps of nearly $300 \mathrm{mts}$, in most likely areas for finding tsetse, based on the presence of forests, bushes and the location of rivers and streams after clearing up to 2-3 meters radius of the trap site. The traps were deployed in a georeferenced locaitons to map and easily display the distribution of tsetse flies on the GIS map. After the identity of tsetse and their sex determined, the arithmetic mean catches per trap per day was calculated for the full sampling periods according to $[40,41,42]$.

\section{Fly dissection and observation of the parasites}

This was achieved on freshly killed flies after immobilizing them by squeezing the thorax gently. After making two small incisions on either side of the tergites 1-3, with the fly on its ventral surface, the gut was allowed be seen, and by placing a cover slip over it and gently pressed down gut contents in a drop of saline solution, the gut contents were examined under a compound microscope using a $10 \times$ eyepiece and $25 \times$ objective. Proboscides from flies were dissected into a separate drop of saline solution and teased apart, gently rubbing a fine needle down the length of the proboscis to dislodge the trypanosomes. The salivary glands were also examined according to guidelines of dissection for trypanosome infection rate in tsetse, [42]. Trypanosome infections in the hypopharynx and labrum (proboscis) only, are classed as Trypanosoma vivax-type; in the proboscis and midgut only as $T$. congolense-type and in the proboscis, midgut and salivary glands as T. brucei-type,

\section{Parasitological}

For parasitological surveys, stratified random sampling method was followed. The target populations were separated at village level, in a non-overlapping strata or sub-populations that are thought to be homogenous such that there is less variation among the sample units in the same stratum and among sampling units in different strata. Afterward, approximation of trypanosome prevalence and identification of the parasite were achieved by collecting blood from sample animals puncturing, aseptically, marginal ear veins with lancet and the blood sucked up by heparinized micro-hematocrit capillary tubes allowing the tubes were filled up to three fourth of their length and sealed at one end with crista-seal. The capillary tubes were centrifuged at 12,000 rpm for 5 min to concentrate the trypanosomes in the buffy coat layer. After the Packed Cell Volume (PCV) was measured, the buffy-coat plasma junction including one $\mathrm{mm}$ of the red blood cells was cut using diamond pencil to pour on the $\mathrm{BC}$ on microscope slide and covered with cover slip of $24 \mathrm{~mm} \times 24 \mathrm{~mm}$ and examined for the presence of trypanosomes, [43]. Thin blood smears were prepared from positive and anemic animals (PCV of $25 \%$ or less). The thin blood smears also checked for other hem parasites such as Anaplasma spp. Babesia spp and Thileria spp. The obtained results recorded for further prevalence determination using the formula for prevalence [44]. 
After a cross sectional baseline data collection to determine the flies' spatial and temporal distribution and risk of trypanosomosis among the herds, animals were treated with deltamethrin $1 \%$, using hypodermic syringe, at belly and legs body parts, as $0.06 \mathrm{ml}$ of formulation per $1 \mathrm{~kg}$ of body weight which is less by $40 \%$ that needed for a whole body (standard) treatment regime applicable as $0.1 \mathrm{ml}$ of formulation per $1 \mathrm{~kg}$ of body weight. To this end, though, other studies recommended that treating 4 large cattle per $\mathrm{km}^{2}$ is considered sufficient to control or eliminate tsetse [27], the current study followed a density of 15 treated animals $/ \mathrm{km}^{2}$. This is because, communal herds in the area typically comprise $25 \%$ young animals (> one year old) and $60-70 \%$ females, and are not evenly distributed spatially or temporally; to achieve sufficient control, the identified regime was followed over a relatively large area $\left(>850 \mathrm{~km}^{2}\right)$, where the participation of many livestock keepers were involved. Meanwhile, many herds from the district were involved in the study wherein, $>55,000$ cattle from 17 villages were treated on three months base, where they were watered at different watering points located in the Ghibe valley and its principal tributaries.

A treatment regimen, in the course of the entire survey times, was followed in which animal found to be parasitaemic using the buffy coat phase contrast technique or animal in which trypanosomes were not detected but with a packed red cell volume (PCV) less than $20 \%$ or any animal suspected of the disease, based on clinical signs, was treated with diminazine aceturate at a dose rate of $7 \mathrm{mg} / \mathrm{kg} \mathrm{BW}$ or alternatively with isomethamedium chloride at a dose rate of $1.0 \mathrm{mg} / \mathrm{kg}$ body weight without charge. But no blanket treatment of animals was achieved and no other tsetse control techniques were employed and single blindness protocol was followed.

\section{Limitations}

Two limitations of this study can be specified; firstly, however, too many other biting flies were collected and identified (Tabanides, stomoxis, heamatopota, etc.) they were not recorded in which the important role of these flies in transmitting trypanosome spp. was neglected. Secondly, however, identification of trypanosome infection rates in tsetse were determined by dissection and observation of the parasites in organs of the fly, an imprecise identification of the trypanosome species subgenera can be made. Therefore, molecular biological diagnostic procedures (DNA probes and polymerase chain reaction, PCR) should have been used. However, since it requires sophisticated laboratories, specialist staff and reagents and is more expensive to perform, we were unable to do so. Besides, ovarian ageing and wing fray analysis for age structure determination should have been done, especially at last monitoring.

\section{Abbreviations}

African animal trypanosomosis (AAT); packed red cell volume (PCV); Cl; Confidence Interval; ANOVA; Analysis of Variance; RLO; Rickettsia-Like Organisms; FTD; Fly per Trap per Day; RAIC; Restricted Application of Insecticide to Cattle; $\left(\mathrm{H}_{0}\right)$; Null Hypothesis ITC; Insecticide Treated Cattle; NTTICC; National Tsetse and Trypanosomosis Investigation and Control Center; SE; Standard Error; T\&T; Tsetse and Trypanosomosis; BW; Body Weight

\section{Declarations}

\section{Acknowledgements}

We are indebted to Mr. Yigremachew Kasahun member of the Bedele T\&T investigation and control center and to Boter Tolay animal health office particularly of the technique staffs for parasitological and entomological data 
collection and participating in the control, and to livestock owners and herdsmen in the district for their enthusiastic cooperation.

\section{Authors' contributions}

DA, conception of the trial, study design preparation, data analysis, data results interpretation, writhing the manuscript and submission; $A B$, data arrangement, reviewed the study design, field monitoring data collection, supervising the activity; BM, reviewed the study design, baseline data collection, following the activity, organizing stakeholders; TA, monitoring data collection, following the activity, organizing stakeholders, reviewed the study design;

\section{Authors' information}

DA, AB, and TA, (Bedele Tsetse and Trypanosomosis Investigation and Control Center, (BTTICC); P.O. Box 113, Bedele, Ethiopia)

BM, (Kaliti Tsetse Fly Mass Rearing and Irradiation Center, P.O. Box: 19917 Addis Ababa, Ethiopia.)

\section{Funding}

The field trial was supported by Bedele Tsetse and Trypanosomosis Investigation and Control Center under Ministry of Agriculture, Ethiopia by providing chemicals and veterinary equipment for the survey in a routine T\&T control activities.None of the authors received a fund and the corresponding author is from low income country, Ethiopia.

\section{Availability of data and materials}

All data generated or analyzed during this study are included in this published article and its supplementary information files and are available from the corresponding author on reasonable request.

\section{Ethics approval and consent to participate}

The study design and the procedures followed in this field trial were reviewed and approved by the Bedele Tsetse and Trypanosomosis Investigation and Control Center scientific research approval Committee, under Ministry of Agriculture

\section{Consent for publication}

Not applicable.

\section{Competing interests}

No conflict of interest exists among the authors themselves and between authors and any organization.

\section{References}

1. MoA (Ministry of Agriculture), 1995. Ethiopian ruminant livestock development strategy. Addis Ababa, Ethiopia, Ministry of Agriculture, p. 112-113.

2. Geerts, S., Holmes, P.H., Diall, O and Eisler, M.C. (2001). African bovine trypanosomosis, the problem of drug Loading [MathJax]/jax/output/CommonHTML/jax.js :5-28. 
3. Rowlands GJ., Mulatu W., Authit E., D’leteren GDM., Leak SGA \& Nagda SM (1994). Effects of trypanosomiasis on reproduction of East African Zebu cows exposed to drug-resistant trypanosomes. Preventive Veterinary Medicine 2 I, 23 7-249.

4. Codjia, V., Mulatu, W., Majiwa, P.A.O., Leak, S.G.A., Rowlands, G.J., Authie, E., d'leteren, G.D.M., Peregrine, A.S., 1993. Epidemiology of bovine trypanosomosis in the Ghibe valley, south west of Ethiopia. 3. Occurrence of population of Trypanosoma congolense resistant to diminazine, isometamedium and homedium. Acta Trop. (The Netherlands) 53(2), 151-163.

5. David Bourn, lan Grant, Alexandra Shaw, and Stephen Torr "Cheap and safe tsetse control for livestock production and mixed farming in Africa." Aspects of Applied Biology75 (2005): 81.

6. Torr, S.J., Stephen J., T. N. C. Mangwiro, and David R. Hall. "The effects of host physiology on the attraction of tsetse (Diptera: Glossinidae) and Stomoxys (Diptera: Muscidae) to cattle." Bulletin of Entomological Research 96.1 (2006): 71-84.

7. Vale, G. A., G. Mutika, and D. F. Lovemore. "Insecticide-treated cattle for controlling tsetse flies (Diptera: Glossinidae): some questions answered, many posed." Bulletin of Entomological Research 89 (1999): 569-578.

8. Torr, S. J., I. Maudlin, and G. A. Vale. "Less is more: restricted application of insecticide to cattle to improve the cost and efficacy of tsetse control." Medical and veterinary entomology 21.1 (2007): 53-64.

9. Fuller, G.K., 1978. Distribution of Glossina in Southwestern Ethiopia. Bull. Ent. Res. 68, 299-302.

10. Langridge, W.P. (1976).A tsetse \& trypanosomiasis survey of Ethiopia. Addis Ababa, Ethiopia, Ministry of Overseas Development of British and Ministry of Agriculture of Ethiopia. pp. 1- 40.

11. Hargrove, J. W. and Langley P.A. (1993): Afield trial of pyiroxyfen-treated targets as an alternative method for controlling tsetse (Diptera:Glossinidae): Bulletin Of Entomological Research ; 83:361-368.

12. Leak, S.G.A., Woudyalew, M., Authie, E.d'leteren, Peregrine, A.S., Rowlands, G.J., Trail, J.C.M., 1993. Epidemiology of bovine Trypanosomiasis in the Ghibe Valley, southwest Ethiopia. Tsetse challenge and its relationship to trypanosome prevalence in cattle. Acta Trop. 53, 121-134.

13. Hargrove, J. W. ((2000) A theoretical study of the invasion of cleared areas by tsetse flies (Diptera: Glossinidae) Bulletins of Entomological Research 90, 201-209.

14. Masingi A.R., Whiteker, C.J., Lahane, M.J. (1998): Factors affecting the prevalence of trypanosome infection of Glossina pallidipes on the Ruvu flood plain of eastern Tanzania. Tropica, 70:143-55.

15. A.J. and Cunningham, M.P., (1971): Immunological aspect of bovine Trypanosomiasis. IV. Patterns in the production of common antibodies. Tropical Animal Health and Production. 3: 133-139

16. Leak, S.G.A. (1998) Tsetse biology and ecology: their role in the epidemiology and control of trypanosomosis. CABI Publishing. Oxford and New York.

17. Welburn, S.C. \& Maudlin, I. (1989): Lectin signaling of maturation of congolense infections in tsetse. Medical \& Veterinary Epidemiology, 3: 141-145.

18. RODER, P.L., SCOTT, J.M., and PEGRAM, R.G. 1984. Acute Trypanosoma vivax infection of Ethiopian cattle in the apparent absence of tsetse. Trop. Anim. Hlth. Prod. 16:141-147.

19. Brown, C. G. D., A. G. Hunter and A. G. Luckins (1990): Disease caused by protozoa. In: tropical animal health (1996), (eds: Horest, S.H. Seifert) George-August University. In: Gottingen, Germany, Pp 165.

20. Acosta-Serrano A., Vassella, E., Liniger, M., Kunz Renggli, C., Brun, R., Roditi, I, England, PT: The surface coat of procyclic Trypanosoma brucei: programmed expression and proteolytic cleavage of procyclin in the tsetse

Loading [MathJax]/jax/output/CommonHTML/jax.js

Page 16/19 
21. Whiteside, E.F., (1958). The control of animal trypanosomosis in Kenya. A paper prepared for IACED symposium (1958). Department of Veterinary Science, Kenya.

22. Jordan, A.M., 1986: Trypanosomiasis control and African rural development. London and New York: Longman 23. Murray, M. and Dexter, (1988). Anemia in bovine African Trypanosomiasis. Acta Tropica. 45, 389-432.

24. Magona, J.W., Mayende, J.S.P., Olaho-Mukani, W., Coleman, P.G., Jonsson, N.N., Welburn, S.C. \& Eisler, M.C., 2003. A comparative study on the clinical, parasitological and molecular diagnosis of bovine trypanosomosis in Uganda. Onderstepoort Journal of Veterinary Research, 70 (3): 213-218.

25. Leak, S.G.A., Mulatu, W., Rowlands, G.J., d’leteren, G.D.M., 1995. A trial of a Cypermethrin 'Pour-on' insecticide to control G. pallidipes, G. fuscipes fuscipes and G. morsitans submorsitans (Diptera: Glossinidae) in southwest Ethiopia. Bull. Entomol. Res. 85, 241-251.

26. Torr SJ, Maudlin I, Vale GA. Less is more: restricted application of insecticide to cattle to improve the cost and efficacy of tsetse control. Med Vet Entomol. 2007; 21:53-64.

27. Vale, G.A.\& Torr, S.J. (2004) Development of bait technology to control tsetse. The Trypanosomiases (ed. by Maudlin, P.H. Holmes \& M.A. Miles), pp. 509- 523.

28. Hall, M.J.R. \& Wall, R. Biting flies: their role in the mechanical transmission of trypanosomes to livestock and methods for their control, pp. 583-594. In Maudlin, I., Holmes, P.H. \& Miles, M.A., eds. The trypanosomiasis. CABI Publishing, Oxfordshire, UK.

29. Vale, G.A. Field studies of the responses of tsetse flies (Glossinidae) and other Diptera to carbon dioxide, acetone and other chemicals. Bulletin of Entomological Research, 70: 563-570.

30. Lysyk, T. J. "Temperature and population density effects on feeding activity of Stomoxys calcitrans (Diptera: Muscidae) on cattle." Journal of medical entomology 32.4 (1995): 508-514.

31. Habtewold, T., Prior, A., Torr, S.J.\& Gibson, G. (2004) Could insecticide-treated cattle reduce Afrotropical malaria transmission? Effect of deltamethrin-treated Zebu on Anopheles arabiensis behavior and survival in Ethiopia. Medical and Veterinary Entomology, 18, 408- 417

32. Rowlands, G.J., Leak, S.G.A., Peregrine, A.S., Nagda, S.M., Mulatu, W.,d'leteren, G.D.M., 2001. The incidence of new and the prevalence and persistence of recurrent trypanosome infections in cattle in southwest Ethiopia exposed to a high challenge with drug-resistant parasites. Acta Trop. 79, 149-163.

33. DAGRIS (Domestic Animal Resources information), 2004. In: H. Lemecha, W. Mulatu, I. Hussen, E. Rege, T. Tekle, S. Abdicho, W. Ayalew, E. (Eds.) DAGRIS, version1. International Live Stock Institute (ILRI), Addis Ababa, Ethiopia.

34. Rowlands, G.J., Woudyalew Mulatu, Leak, S.G.A., Nagda, S.M. and d'leteren, G.D.M., 1999. Estimating the effects of tsetse control on livestock productivity a case study in southwest Ethiopia. Tropical Animal Health and Production, 31(5), 279-294.

35. NTTICC (National Tsetse and Trypanosomosis Investigation and Control Center). Annual Report on Tsetse and Trypanosomosis Survey, 2004. Bedelle, Ethiopia

36. Thrusfield, M. (2005). Veterinary Epidemiology. $2^{\text {nd }}$ edition, Oxford, Blackwell Science Ltd., Pp 182-198

37. Von Braun, J. and Detlev, P. (eds.), 1993. Data need for food policy in developing countries, IFPRI (International Food Policy Institute), Washington, DC, USA.

38. Joint FAO/IAEA Programme of Nuclear Techniques in Food and Agriculture, Vienna, Austria, 2008. In: Stephen G. A. Leak, Dejene Ejigu, Marc J. B. Vreysen (Eds.) Guideline 1. Food and Agriculture Organization of the United 
39. Hall, D.R., Beevor, P.S., Cork, A., Nesbitt, B.F. \& Vale, G.A. 1-Octen-3-ol: a potentolfactory stimulant and attractant for tsetse isolated from cattle odours. Insect Science and its Applications 5: 335-339

40. Buxton PA: The natural history of tsetse flies. Memoir 10 London School of Hygiene and Tropical Medicine. London: HK Lewis; 1955.

41. Mulligan, H.W., ed. The African trypanosomiasis. George Allan and Unwin. London, UK.

42. Food and Agriculture Organization (FAO). Training manual for tsetse control personnel. Volume 1. Tsetse biology, systematics and distribution; techniques. FAO, Rome, Italy.

43. Murray M, Murray PK, Mclntyre WIM (1977): An improved parasitological technique for the diagnosis of African trypanosomiasis. Transactions the Royal Society of Tropical Medicine and Hygiene 7 I (3), 25-26. 44. FAO, (1998): A field guide for the diagnosis, treatment and prevention of AAT. Uilenberg, G. FAO, Rome

\section{Figures}

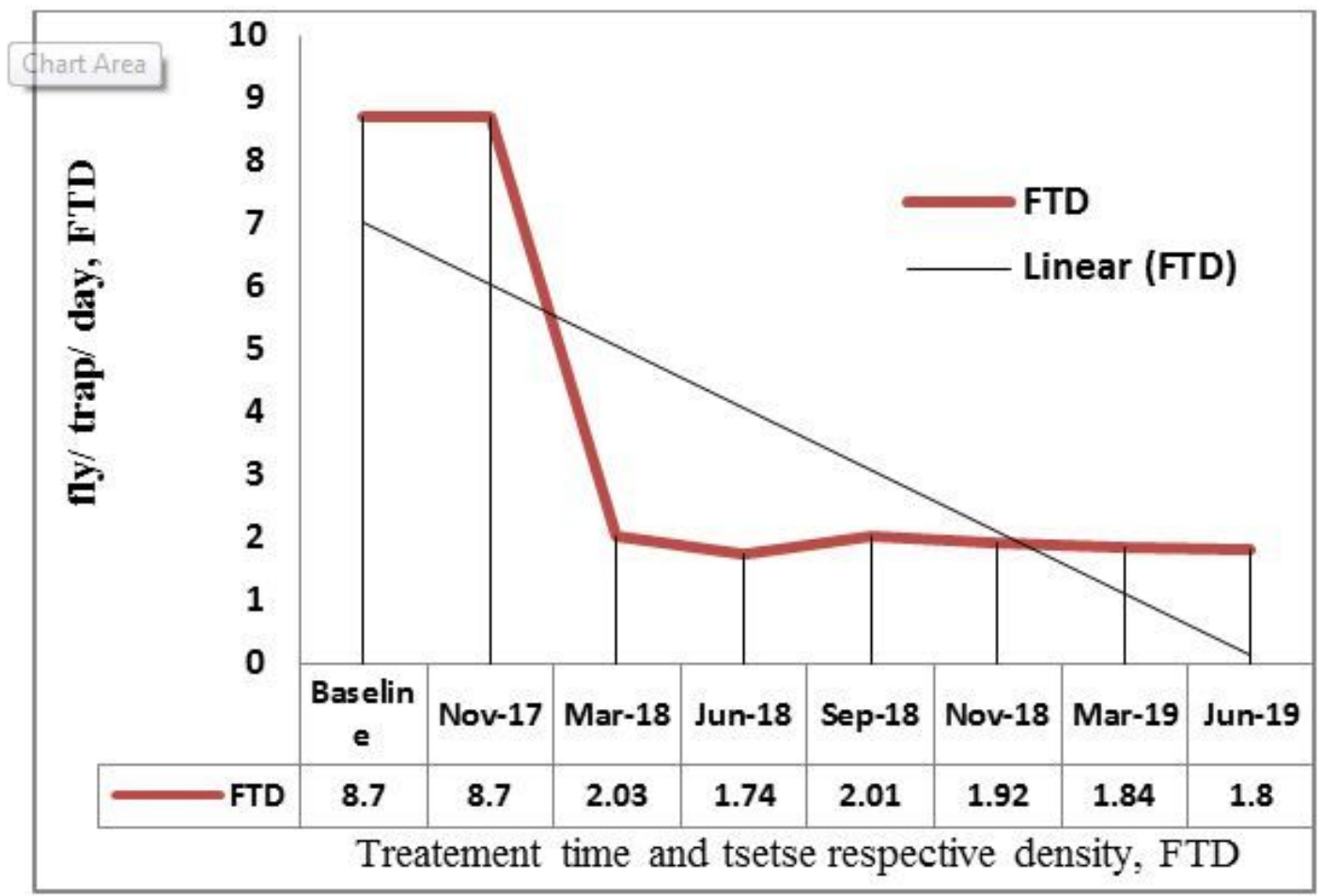

Figure 1

Impact of RAIC technique on tsetse density and its future linear trend to suppress tsetse

\section{Supplementary Files}

This is a list of supplementary files associated with this preprint. Click to download.

- ARRIVEchecklist.docx

- ReviewedAbstract1.docx

- ReviewedmanuscriptforBMC.docx

Loading [MathJax]/jax/output/CommonHTML/jax.js 
- TTDataforBotorTolay.xlsx 